University of Rhode Island

DigitalCommons@URI

Open Access Master's Theses

1997

\title{
A STRATEGIC RECYCLING PLAN FOR U.R.I
}

Amrita Roy

University of Rhode Island

Follow this and additional works at: https://digitalcommons.uri.edu/theses

\section{Recommended Citation}

Roy, Amrita, "A STRATEGIC RECYCLING PLAN FOR U.R.I" (1997). Open Access Master's Theses. Paper 520.

https://digitalcommons.uri.edu/theses/520

This Thesis is brought to you for free and open access by DigitalCommons@URI. It has been accepted for inclusion in Open Access Master's Theses by an authorized administrator of DigitalCommons@URI. For more information, please contact digitalcommons-group@uri.edu. 


\section{A STRATEGIC RECYCLING PLAN FOR U.R.I}

BY

AMRITA ROY

A Research Project Submitted in

Partial Fulfillment of the

Requirements for the Degree of

Master of Community Planning

UNIVERSITY OF RHODE ISLAND

1997 
MASTER OF COMMUNITY PLANNING

RESEARCH PROJECT

OF

AMRITA ROY

Approved:

Major Professor

hay lm and

Acknowledged: 


\begin{abstract}
A. Statement of Problem

Inadequate planning coupled with non-mandatory recycling practices has lead to a low recycling response at the University of Rhode Island. The student, staff and faculty suffer from lack of awareness of the appropriate recycling procedures. Compared to successful recycling initiatives in schools all over the country, URI falls low on the scale.

In June 1989 , URI started a campaign to implement campus wide recycling. The goal was to achieve $12 \%$ recovery rates (this is percentage of amount of materials by weightage that recycled out of the total waste stream) by 1993 . It is unfortunate that in the year 1997 , the rates are still as low as $9.6 \%$.

The time is now ripe to reconsider the whole process of waste management on campus. It is imperative to start with a willingness to change the behavior that accounts for this low response. Careful plans need to be implemented within budget constraints.

\section{B. Project Boundary}

The project boundary includes the URI Kingston campus which includes the residential complexes. There are 19 residence halls and three graduate and faculty apartments.
\end{abstract}




\section{Description of Methods}

Recycling has long been important to reduction of waste disposal. This report is aimed at making recommendations for improving the recycling process at URI. Methods employed at making these recommendations include an overview of successful recycling efforts of other universities. Consequently, the present recycling scenario at the University of Rhode Island is outlined. Personal interviews with waste managers from other universities and personal experience with the project while working at the Housing and Residential Life office, provided valuable input into the design of realistic recommendations.

On-line discussion of recycling initiatives at other schools helped in carving administrative and spatial recommendations for URI. These ideas are to be considered rationally and with caution of not speeding up the process. As a result, the last chapter clearly states the key stakeholders in the recycling planning process. It also outlines the tasks of these players and the timelines within which to achieve the same.

\section{Scope}

The students are the future trustees of Earth's soon depleting non-renewable resources. The relevance of such a recycling plan go far beyond the boundaries of the campus. This recycling plan hopes to serve as a guide for the waste manager as well as for the entire campus community. A framework may be developed eventually to evaluate the success of the program over time. Any program is incomplete without feedback and evaluation. This plan anticipates 
mobilization of the campus community to aim for higher standards of environmental awareness. 


\section{ACKNOWLEDGMENTS}

I would like to thank Rolf Pendall for being a patient and supportive advisor and Marcia M. Feld for her encouragement and advice. A heartfelt appreciation goes out to Nancy Hawksley for being the independent reader and also a friend during my entire stay at U.R.I. Special gratitude to all the waste managers of different schools for their time and willingness to help with this project.

On a more personal note, I would like to express deep gratitude to my parents for being my closest friends and for believing in me. A thank you to my sister for being a guide and a confidant. Special gratefulness is also extended to Chip Yensan, Director of HRL, for being my mentor at work and outside. Finally, an indebtedness to all the people at URI who touched my life with gentleness. 


\section{TABLE OF CONTENTS}

CHAPTER

PAGE

ABSTRACT ..................

A. Statement of Problem . . . . . . . . . . . . . i

B. Project Boundary . . . . . . . . . . . . . . . . . i i

C. Description of Methods . . . . . . . . . . . . ii

D. Scope ....................... ii

ACKNOWLEDGMENTS ................. . iv

TABLE OF CONTENTS . . . . . . . . . . . . . . . v

I. SUCCESSFUL RECYCLING EFFORTS OF OTHER

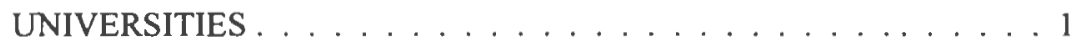

II. PRESENT RECYCLING SCENARIO AT U.R.I . . . . . . . . 13

III. ADMINISTRATIVE AND SPATIAL RECOMMENDATIONS

FOR U.R.I RECYCLING . . . . . . . . . . . . . . . . 23

IV. IMPLEMENTATION STRATEGIES

FOR U.R.I RECYCLING . . . . . . . . . . . . . . . . . . . . 37

REFERENCE LIST .. . . . . . . . . . . . . . . . . . . . 44

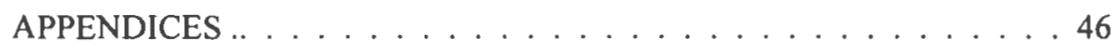
A. Kingston Campus Map
B. Residence Halls Location Map
C. The R.I General Laws for Recycling
D. Recycling and Solid Waste Removal Specifications for U.R.I
E. U.R. I Recycling Poster
F. PACE Committee Recommendations 


\section{SUCCESSFUL RECYCLING EFFORTS OF OTHER UNIVERSITIES}

Chapter I

\section{INTRODUCTION}

Universities all over the United States are striving to make their campuses environmentally conscious. Various humorous and powerful slogans about waste reduction are an integral part of the campus. Waste managers are hard at work to make the campus community environmentally aware. To quote a slogan from University of California, Davis, "Be a refiller not a landfiller" and "Before you're through, use side two". These slogans are found in most of the reusable mugs and on table tents in the cafeterias. These kinds of slogans are not exclusive to UC Davis, but are common to almost all campuses around the country. "University environmental campaigns grew due to a wave of consciousness that pushes for a better tomorrow. It is usually the 'few good people' on campus who initially start the crusade mainly so that the college experience is more than the just about degrees / diplomas. They aspire to make the student an environmentally aware individual who would take this experience beyond the campus boundaries" (Ecodemia, 1995).

In 1991, Jack DeBell, Recycling Coordinator for University of Colorado at Boulder, conducted a national survey of campus recycling. The survey showed that more than $78 \%$ of the US institutions of higher education had fairly wellestablished recycling programs. He says that while $30-40 \%$ recovery rates are 
not unusual on campuses, mandates seldom exceed $25 \%$ (Ecodemia, 1995). Recovery rates are the percentage of materials by weightage that are recycled out of the total waste stream.

A big push for environmentally conscious campuses came in 1994 after the Campus Earth Summit was held at Yale University. This energy round table helped to produce a very important document called the Blueprint for a Green Campus (Heinz Foundation Report, 1995). This document became the bible for many waste managers in many campuses. It consists of series of recommendations regarding improvements in the higher education curriculum and energy conservation techniques. It has also encouraged students to take up valuable research as part of their undergraduate or graduate programs compatible with their educational missions.

Experience from other campuses show that common themes emerge. Firstly, a few committed individuals need to start the campaign and then the rest would follow. Also it is important to get the students, staff and faculty all involved while also getting the school officials enthusiastic. Hopefully, all these efforts would lead to the pursuit of a healthier planet.

"The reasons for stressing waste prevention at colleges and universities go far beyond targeting their contribution to the nation's waste burden. Colleges and universities have the potential to serve as models of waste prevention that students can bring to the working world after graduation. They also serve as models for their communities and for alumni and benefactors scattered across 
the country, due to their educational mission, high community visibility, active involvement in research, development, and new technologies, and the role in disseminating information through conferences and publications" (Saphire,1995). "Recycling has long been important to reduction of waste disposal. It has become significant recently as a major source of revenue as well. A number of local areas have reported that recycling has reduced the cost of municipal waste collection and disposal (Young John, 1995). "Recycling is very important and universities can do a lot. In the larger social context, if the recycling effort could grow within the campus, it can be a major mobilization force in the local community" (DeBell,1994).

"Campus recycling has become a bonafide profession and more and more institutions are reusing materials and reducing waste" (USC Env. Audit, 199596). Millions of college and university students are growing more accustomed to the idea of living in a world of consciousness of environmental issues.

\section{EDUCATION AND PUBLICITY}

"On campuses around the country there are many things that students, faculty and staff are doing. They are all searching for practical ways to use materials more efficiently, to prevent the creation of waste, and to promote recycling of waste that is created. A ton of waste not created is a ton of waste that doesn't have to be managed " (Saphire,1995). 
Different campuses emphasize different aspects of recycling, but almost all would agree that education is probably the urgent need. Diversion rates/ recovery rates are good ways to measure the participation rate over time. These rates are often published on campus newsletters and flyers either weekly, daily or monthly. This helps to gauge the success or failure of the program. For example, University of Wisconsin, Eau Claire, on its college web page presents figures for the amount of recyclables collected even as precisely as each week. Also clearly stated in the web page is the state statute that mandates the university to recycle.

(URL:http://www.uwec.edu/admin.facmgt/recycle.html).

Each campus has unique physical and demographic characteristics. However, what is common to all campuses is that they are composed of students, faculty and staff. This interesting combination of individuals is usually open to new ideas and lend themselves as an eager learning audience. Also, these students are tomorrow's parents and the working class, and implanting in them an environmental sensitivity would only prove to be advantageous.

Competitions are a good way of encouraging recycling. Some universities compete either between residence halls or departments. It is easier, however, to measure the success of the residence halls because the total population is known. At the University of Colorado at Boulder, residence halls which rank first, second and third in the amount of materials recycled per semester, are awarded $\$ 450, \$ 200$ and $\$ 100$ at the end of the semester. The year end winner gets a 
green cup made of recyclable materials. Smaller prizes every week however, are better because they serve as a constant reminder of the advantages of recycling. Also, this inculcates competitive spirits among the students.

"In 1990-91, Harvard university started its own Green Cup competitions. These are contests between residence halls and are based on energy and resource conservation. The winning dorm gets money awards that can be used for either physical / infrastructure improvements or other extra curricular activities. George Washington University, the University of Wisconsin at Madison, Tufts University, are only a few example of those who have followed the Harvard model" (Ecodemia, 1995).

College campuses all over the country are trying to communicate to the students, staff and faculty about the advantages of recycling.

An important part of the educational campaign is also to state clearly the basics of recycling and waste management. This might require the students need to make an added effort to recycle at first. Hopefully, with time it would become second nature to them. In order to achieve this, effort has to be made to clearly state the acceptable materials that can be recycled. This helps to alleviate any uncertainty that the student might feel about what to separate for recycling. Many colleges create their own web pages that the campus community can easily access. For example, UC Davis college web page clearly states and shows materials that can be recycled. Visuals clarify any doubts about the materials that can be sorted. 
Workshop slogans and educational campaigns are all part of the educational effort. Slogans and recycling logos on mugs, bins and bulletin boards are other powerful methods of communication. This greatly helps to educate the students because mugs are a commonly used commodity. A constant 'in the face' kind of advertising and educational campaign can bring attention to the fact that the Earth's resources are non-renewable and hence need to be protected.

Some universities conduct recycling surveys either as part of the mid-year assessment survey or as a separate one in most universities. Resident assistants talk about recycling during their weekly meetings. A weekly

informational session for the students can be held on a rotational basis, so that if a student misses it one week he/she can go to the other dorms to hear the information.

Universities are spending a lot of money on publicity for waste reduction. For example, University of New Hampshire spends around $\$ 1000$ a year on publicity (Telephone interview, Recycling Coordinator, UNH, April 1997).

\section{COLLECTION PROCEDURES}

Collection procedures refer to the sorting and collection of recyclable materials. Campus recycling coordinators all over the country are trying to participate in conferences/ dialogues to find out new and innovative ways of communicating about waste reduction to the campus community about waste reduction. One 
such on-line discussion list is the Recyc- $L$ list for college and university waste managers.

Source reduction, which is a more recent phenomenon, is another effective way of helping the university reduce waste. As the name suggests, this means using less materials, for example buying products which are reusable or need less packaging or making double sided copies. White paper is usually the most widely used and recycled commodity on campus (USC, Env. Audit, 1995-96). It is usually most commonly separated at the source near the computer printers, or copying machines etc. Double-sided copies are often used while making copies or printing unfinished documents to prevent wastage. Other efforts towards source reduction are the use of e-mail instead of sending memos and printing fewer reports that could be shared or kept in the library for reference. The counterpart to a good collection procedure is the prevention of contamination. There are various methods that universities are employing in order to determine the level of contamination in the recycling containers. Contamination is defined as having non-recyclables in the recycling containers which then renders the whole toter as useless. Some universities have monitors or volunteers that count the number of contaminants in the toters. This helps to track the contamination in the bins over a period of time. The monitors give points to each bin and figure out the department or the dorm which is responsible for the contamination (Yale University, Connecticut). 
Some universities (e.g. U.C Santa Cruz) conduct quarterly room inspections to ensure the base level of cleaning and check for damages. Apartments have stack bins for recycling. Bins are listed in the inventory right along with furniture, and tenants are charged for replacements and/or damages.

Bolder efforts to encourage recycling include the use of physical posts which look like the parking 'stop signs' but instead are white with red letters. This necessitates the person to stop and think if they are recycling or merely trashing their materials. This way the student / staff takes a moment to put the appropriate material in the designated containers.

"Finally, waste prevention almost always leads to savings on procurement and operations as well as savings on waste management and disposal" (Saphire, 1995).

Most universities have recycling bins on each floor of the building which are then emptied by the janitorial staff either daily, weekly or twice a week depending on how full the containers are. As a result of this stream of materials, the janitors play a very important role in the success of a recycling program.

\section{DEPARTMENTAL COOPERATION}

It has been the experience of many universities that departmental cooperation is essential for any type of campus program to flourish. This means that not only the Physical plant (or the like) has to cooperate with Housing offices, but also 
other departments like purchasing, printing and dining services need to be involved in waste management programs.

Only recently (in the past decade) there has been a greater push for cost saving mechanisms in waste reduction (Saphire, 1995). This requires an accurate account of the materials that are diverted from the waste stream. Once this data is available then the waste managers can start to think about 'closing the loop', that is it is important to not only divert materials, but also to buy recycled goods. This parallel would then get the purchasing department of the universities involved. This pattern would slowly integrate every part of the university community to work towards a greener campus.

Departmental cooperation includes not only inter-departmental communication but also intra-departmental cooperation. Having the support of the school budget and research offices is also very crucial. This leads to the positive flow of ideas and information leading to a more tolerant environment.

Reuse of printed paper is also another way that the departments can work together. Packaging also adds to the waste stream. "The most common transport container is the cardboard corrugated box, which is typically used just once. Corrugated cardboard boxes accounted for $12.7 \%$ of the U.S municipal solid waste in 1993" (Saphire, 1995). Reusable packaging can be requested by the purchasing department and can be made an integral part of their purchasing policy. Two way envelopes are also good ways to control waste. 
Table No. 1

\begin{tabular}{|c|c|c|c|c|}
\hline & $\begin{array}{l}\text { Univ, of } \\
\text { Calffornt, } \\
\text { Davis }\end{array}$ & $\begin{array}{l}\text { U of Narthern } \\
\text { Texas }\end{array}$ & $\begin{array}{l}\text { U of Chicago, } \\
\text { Ilinois }\end{array}$ & $\begin{array}{l}\text { Enthigart } \\
\text { University }\end{array}$ \\
\hline $\begin{array}{l}\text { Education, } \\
\text { Publicity }\end{array}$ & $\begin{array}{l}\text { Posters and } \\
\text { brochures regularly }\end{array}$ & $\begin{array}{l}\text { Commitment } \\
\text { statements signed by } \\
\text { students for } \\
\text { compliance. Dorm } \\
\text { contests. }\end{array}$ & $\begin{array}{l}\text { Constant } \\
\text { reinforcement. } \\
\text { Laminated handouts } \\
\text { behind the room doors. } \\
\text { Table tents in dining } \\
\text { halls }\end{array}$ & $\begin{array}{l}\text { Variety of } \\
\text { media. }\end{array}$ \\
\hline Collection Procedures & Bins on every floor & $\begin{array}{l}\text { Bins on each floor, } \\
\text { Janitors pick up only } \\
\text { recyclables from the } \\
\text { rooms not trash. } \\
\text { Bins to central location } \\
\text { inside the building. }\end{array}$ & & $\begin{array}{l}\text { Limit the } \\
\text { articles to be } \\
\text { collected. } \\
\text { Student hall } \\
\text { govt. separates } \\
\text { the recyclables } \\
\text { in } \\
\text { compartmentali } \\
\text { zed locked } \\
\text { bins. }\end{array}$ \\
\hline $\begin{array}{l}\text { Department } \\
\text { Cooperation }\end{array}$ & $\begin{array}{l}\text { Printing and } \\
\text { Purchasing }\end{array}$ & & & $\begin{array}{l}\text { Printing and } \\
\text { Purchasing } \\
\text { Self hauling to }\end{array}$ \\
\hline Hauling Contract & Outside contract & Outside contract & Outside contract & $\begin{array}{l}\text { market with the } \\
\text { best price for } \\
\text { the materiais }\end{array}$ \\
\hline
\end{tabular}

As can be seen from the above table, each university deals with the waste reduction process in different ways. This is often times dependent on the availability of funds, the support of the school authorities, student initiatives or other socio -economic factors. The point that becomes clearer after looking at this table is that educating students, staff and faculty can become instrumental in increasing participation and compliance.

\section{HAULING CONTRACTS}

Hauling contracts are contracts that a university can have with an outside vendor which would be responsible for the disposal of campus waste. Most universities 
pay a fixed amount for tipping fees (this is the fee paid for waste disposal) which is set out in the bid specifications initially.

In recent years, some of the universities (e.g. UMASS, Amherst) have been able to buy their own waste disposal trucks. They transport the recyclable materials to various locations depending on the market rate for the sale of these materials.

\section{MATERIALS RECYCLED}

Most universities are mandated by the state laws to recycle certain commodities such as aluminum cans, glass bottles, office paper, mixed paper, cardboard and newspaper. However, universities are also aiming for other sophisticated materials that could be recycled. One of these is the disposal of hazardous waste. The other is to use the food waste from dining services for composting. Although composting is not essentially part of recycling, it does fall into the category of waste reduction and reuse. University of Vermont composts food waste and uses it for animal bedding (Interview, UVM Waste Manager, March 19, 1996).

All the above broad categories discussed help in focusing on the importance of a sound recycling plan.

\section{CONCLUSION}

Over the last decade, universities all over the country have made some effort towards greener and more environmentally safe campuses. Some have taken 
small steps while the others more bold strategies. The essential idea is to take a stand because ideas percolate fast in a university setting.

To quote Julien Keniry," Environmental responsibility creates common ground" (Ecodemia, 1995). The future for greener campuses looks encouraging and will soon become a determining factor for students choosing their places of higher education. The University of Vermont currently advertises its campus as an 'environmental campus' and expresses it as an integral part of the campus culture (Interview, Solid Waste Manager UVM, March 1996) . The next chapter will show that URI has not used majority of these approaches. It can start improving the recycling scenario by educating the campus community about the numerous advantages of recycling. In order to address some of the problems of low participation, recommendations will be proposed in the chapter 3. However, in order to propose recommendations, first the present recycling processes need to be studied. This will be dealt with in the following chapter. 


\section{PRESENT RECYCLING SCENARIO AT THE \\ UNIVERSITY OF RHODE ISLAND}

\section{Chapter II}

\section{BACKGROUND}

In June 1989 , The University of Rhode Island started a campaign to implement campus wide recycling. A goal was set to achieve $12 \%$ recycling by 1993 . At present, URI landfills 3200 tons of waste a year (1994-95) out of which $9.6 \%$ is recycled or diverted from the waste stream (Facilities and Management Annual Report, 1995). This figure compared to the figure of $9 \%$ in 1989 shows a slight improvement but there is room for more improvement. Although URI encourages recycling, it has fallen short of its goal.

Comparisons to other universities show that URI can do better. Some universities develop recycling programs either as part of waste management or as a separate program in itself. For example, the University of Vermont diverts $45 \%$ of the waste towards recycling (Interview, March 1996). Some universities divert food waste, paper and cafeteria residuals to convert to organic manure which makes composting a profitable enterprise (Fulton, 1993). If the recycling effort could grow within the campus then not only could the university earn valuable revenue in terms of lower disposal fees, but this would also increase environmental awareness among the student population.

Some reasons for low participation and diversion rates could be attributed to the following :- 
1) No apartment recycling

2) No incentives

3) No student initiative

4) Poor collection techniques

\section{URI PRESENT RECYCLING STATUS}

The University of Rhode Island (URI), like any other university, generates a considerable amount of solid waste, providing numerous opportunities for waste reduction and recycling. URI has four campuses, the Kingston campus, the Narragansett Bay campus, the College of Continuing Education and the Alton Jones campus. However, for the purpose of this study, only the Kingston Campus will be considered because it houses the residential population. See Appendix $A$ for the Kingston Campus map.

According to the URI Recycling and Solid Waste Removal Specifications, the Kingston Campus is about 1200 acres in size and the Bay Campus (six miles to the east) is about 150 acres in size. The University contains about 40 apartment buildings (out of which 19 are residence halls). This houses approximately 4000 students and 400 families. All the residence halls are located within walking distance from each other and the dining halis. See Appendix B for location of residence halls on campus.

According to the records of the RI Department of Environment Management (RIDEM), URI generates approximately 3000 to 4000 tons of waste a year from 
both these campuses. Previous RIDEM records show that the percentage of material diverted for recycling has changed insignificantly since the inception of the recycling program (URI Waste Reduction and Recycling Annual Reports, 1992-93, 1993-94 and 1994-95). Efforts to plan waste reduction and recycling started in early 1988. According to the Facilities and Operations report of 1995, the events which led up to the present recycling program were created in part by legislation mandating commercial recycling, rising costs of land-filling trash, and the emerging sense of environmental concerns by society. URI by definition is a generator of commercial solid waste and is required by the General Laws of Rhode Island to segregate the recyclables from its waste stream (Facilities and Operations Recycling Report 1995). As a result the tipping fees that URI pays is at the commercial rate rather than the low municipal rate (Ibid. Report 1995). The present research will be divided into following five broad categories. These are materials for recycling, education and publicity, collection procedures, hauling contract and departmental cooperation.

\section{MATERIALS FOR MANDATORY RECYCLING}

Rules for Reduction and Recycling of Commercial and Non-Municipal

Residential Solid Waste require the following materials to be recycled:

Aluminum

Automobiles

Coated, unbleached kraft beverage carriers

Corrugated cardboard

Glass food and beverage containers

Laser printer toner cartridges

Leaves and yard waste

Wood waste
Office Paper

Plastic containers

Phone directories

Tin coated steel cans / steel cans

Used lubricating oil

Vehicle batteries

White goods 
The state mandate encourages commercial waste disposers to employ new and improved techniques to divert recyclabes from the waste stream. This is in order to promote environmentally acceptable and economically sound solid waste management. URI could also look into the feasibility of reducing or disposing of hazardous waste from the campus because of high expenditure of chemicals in the laboratories.

\section{EDUCATION AND PUBLICITY}

Campus waste managers all over the country have given highest priority to the education element for a successful recycling program. This can be done in a number of ways. At present the recycling information is carried in the campus phone book. There is no separate educational effort made to make the student aware of the recycling procedures. Education starts with the 'blue we recycle' bucket in each room and other bins all over campus. These bins specify the acceptable materials in broad categories. However there is often confusion about the different categories of acceptable materials. There is a lack of bold planning strategies to deal with this extremely important element of education and publicity. 


\section{COLLECTION PROCEDURES}

The 19 residence halls on campus have different configurations, ranging from the single room type, double room hallways to the suite type halls. There are also the spiral type rooms where three students can be housed. Whatever the type of hall, each room is provided with a blue "recycle bucket" to recycle paper, cans or commingled materials. The students are responsible for emptying their own trash as well as recyclables into the appropriate containers outside the residence halls. The janitors do not empty anything from the student rooms, only from the common hallways, lounges, laundry rooms and bathrooms. The recycling containers outside the residence halls are marked for appropriate collection by different colored recycling symbols. These symbols are often unpainted or not clearly visible. Sometimes these containers are placed in between residence halls to be shared. This requires the student to walk for a distance in order to recycle materials.

At present there are no recycling containers provided in the graduate and faculty apartment complexes. Only one dumpster for trash pick up per area is provided. With proper education these families and students can help in increasing the participation rates.

\section{DEPARTMENTAL COOPERATION}

The recycling process is overseen by Housing and Residential Life (HRL) office in the residential complexes and by Facilities and Operations (Lands and 
Grounds) for the remaining campus. The fraternities and sororities on campus are administered as separate entities and not part of HRL. Furthermore, Dining Services is also separate from either HRL or Lands and Grounds (L\&G). This creates certain operational problems because the trash leaving the Dining Services cannot be controlled by the HRL and it is part of the general waste stream.

As a result of dual management by $H R L$ and $L \& G$, there is lack of clarity on responsibility in certain common areas such as the walkways between the residence halls. This calls for an urgent need for inter-departmental cooperation especially between these two departments which is presently minimal (Personal communication, HRL Recycling Coordinator, April 1997).

\section{HAULING CONTRACT}

URI falls under Regulations for Reduction and Recycling of Commercial and Non- residential waste for the State of Rhode Island and Providence Plantations (General Laws of RI, Ch.23-18.9-7, 23-19-5). See Appendix C for Rules and Regulation on Recycling as it relates to U.R.I. This regulation seeks to address the growing concerns related to solid waste generation and disposal. This is administered by the Rhode Island Department of Environmental Management, Office of Environmental Coordination.

The current waste contract for the years 1995 - 1998 is with T \& J Container Systems. This solid waste contractor collects and hauls the solid waste from 
campus to the Materials Recovery Facility. In no case is the contractor allowed to transport source segregated materials to a 'burn to energy' facility (Waste contract 1995-98). The current contract ensures that the University pays for all the tipping fees at the rate of $\$ 116.00$ a ton for recyclables. See Appendix $D$ for greater detail.

T \& J Container Systems, provides all the labor, materials, containers, tools, equipment and total services for removal of solid waste and recyclables from the Kingston campus and the Narragansett Bay campus. T \& $J$ also provides for all the pick-up and hauling of solid waste and recyclable including all fees and licenses required for disposal.

According to the contract, the vendor must provide URI with weekly information about the amount and type of trash and recyclable leaving the campus. The contract also stipulates that the vendor provide front end loading containers, newly painted, fully operable and labeled for collection at the locations specified. Kingston Campus shall follow different schedules for the period of September 1 through May 31 and alternate summer schedule. Containers will be clearly marked, labeled and painted in a contrasting color from trash containers. Trash pick ups are scheduled each day of the week and recyclables are collected on every Thursday. Additionally, the vendor is required to provide a recycling coordinator for the duration of the contract to assist the university in managing the recycling program, developing community awareness, monitoring collection and disposal, and providing technical information as part of the recycling service. 
The contract also requires the vendor to provide "service ticket" for the amount and type of materials collected from each roll-off container. These conditions are generally not met. This information is extremely important and would help in tracking the success or failure of the recycling program.

Campus residents often complain about the poor condition of the trash containers and the recycling toters. The area around the dumpsters is found dirty and unorganized. The hauler is not only supposed to clean after trash pick ups but is also responsible for replacing and/or maintaining the containers that have been vandalized. The hauler is also required to maintain visible recycling labels to make it convenient for students to separate their trash. The vendor does not provide the weekly reports, the labels, service tickets or the support of the recycling coordinator (Interview, Asst. Director L\&G).

The present contract is for a period of three years and is being reviewed by an independent committee. This committee was established as a sub part of the President's Advisory Committee on the Environment (PACE). It is called the subcommittee on Waste Reduction and Recycling (WRR). This committee conducted an in-depth study of the recycling process at URI. See Appendix F for details of these recommendations. The goal of this committee is to look at every aspect of waste on campus and make realistic specific recommendations to improve the situation. WRR recently (January, 1997) made recommendations to the President which would eventually be incorporated as action plans and/or 
as part of the Master plan for URI ( Personal communication, Recycling Coordinator).

One of the most important administrative and spatial recommendations of this research is to implement the ideas put forward by WRR.

\section{CONCLUSION}

In order for the present recycling scenario to improve and come up to the level with other universities across the country, a waste audit is urgently required. Accuracy on the part of the vendor will help in gauging the success of the recycling program. URI also needs to aggressively initiate educational campaigns regarding recycling. Although there has been some initiative, a much more aggressive approach is needed. There needs to be a sense of place instilled in the minds of the campus community. This will encourage higher participation rates and community stewardship.

The next chapter offers recommendations drawn from other universities that URI can follow for a more successful recycling program. The chapter will make a comparison with specific universities and then focus on how to use newer and better strategies at URI to encourage recycling. At present URI falls far below the state mandate for commercial recycling. As time goes by, political and social pressure to reduce waste will rise. The key lies in starting with a small scale program while educating the students on a large scale. Cost effective 
techniques to recycle are a good way to win the support and encouragement of the school authorities. Other schools that match the demographic and physical setting of URI can be taken as a role models while also adopting the more achievable things from other successful universities. 


\section{ADMINISTRATIVE AND SPATIAL RECOMMENDATIONS \\ FOR URI RECYCLING \\ Chapter III \\ INTRODUCTION}

As time passes, universities all over the country become more and more aware of the benefits of waste reduction and recycling. Each university has a different demographic / physical makeup. With respect to URI, carefully planned approaches need to be put forward. One of the biggest drawback for the university is the absence of a master plan leading the future direction of the campus. In term of diversion rates, URI is still struggling to reach the state recycling mandate of $20 \%$.

URI needs to set a good example and create an environmentally friendly campus so that the ideas percolate to the neighboring communities. In the future, a more regional approach could be taken to deal with some of the pricing issues of recycled materials. This could make the market more receptive to recycling materials. An immense effort needs to be made in order to achieve these high standards of recycling.

Comparison of recycling efforts with other schools in New England shows that URI can do a lot better. The three other comparable schools are Brown University, University of Massachusetts, Amherst (UMASS) and University of New Hampshire (UNH). References will be made to these schools where 
appropriate to show successful initiatives. Brown University is also located in Rhode Island and is a pioneering institution regarding recycling. The 'Brown is Green' effort is a well known initiative. UNH and UMASS are also doing extremely well in waste reduction and recycling. They employ simple yet powerful means of communication and also simple collection procedures which prove instrumental in improving diversion rates.

As in the previous chapter, this chapter will also review the five main areas of concern. These are the materials recycled, education and publicity, collection procedures, departmental cooperation and the hauling contract.

\section{MATERIALS RECYCLED}

The materials currently recycled at URI are only part of what is mandated. Paper and aluminum together compose the highest percentage of materials recycled (Annual Report, L\&G 1995). In future, other materials could be included in the list of materials to be recycled. These include automobiles, white goods (appliances), vehicle batteries, laser printer toner cartridges, used lubricating oil, telephone directories and scrap metals. Brown university includes all these other materials as part of the recycling program specifications and requires that all these be recycled on a regular basis (Recyc-L, 29 March, 1995).

For URI however, attaching additional materials to be recycled at this early stage would lead to a premature death of the program. This is because it has the potential of confusing the students. These should only be encouraged when 
participation increases. It is proposed here to start with only the basic materials like newspaper, co-mingled and mixed paper. The bins should be color coded and the specifications advertised. See Appendix. E for more details. One of the drawbacks of less publicity about materials is the danger of contamination. It takes only a few articles not belonging in the recycling bins to render the whole collection useless.

Thus, one of the important recommendations would be to conduct a campus wide waste audit to recognize the articles that go into the waste stream and the specific generators. This would enable the waste manager to determine the specific articles to target for recycling.

\section{EDUCATION AND PUBLICITY}

An extremely important first step for URI is to give top priority to the education element of recycling. This is the only way in which there will grow an awareness that is lacking on campus. This will also help in avoiding contamination and increase operational savings.

It is essential however, to target the different customer groups. Although the scope of this research is confined only to the residence halls and apartments, the education and publicity needs to traverse the entire campus. Universities like UNH and UMASS, have special education programs that target these groups. For example, table tents in the dining halls are for reaching out to resident students and thus increasing the probability of compliance. 
As for URI, the target groups are the commuter students, the students in the traditional residence halls, the Graduate Terrace apartments on campus (to be called the University Terrace in the Fall) which consists of a mix of Graduate and Upper Class (Junior and Senior) students and the Faculty apartments. Graduate village residents are unique in that they range from international students to students with families. All these groups need specialty information brochures depending on the demographics and the physical layout of the building. One of the most important recommendation of this research is to maximize the use of the already existing resources on campus.

a) Articles and advertisements in the campus newspaper are a good way to communicate. This 'Good Five Cent Cigar ' newspaper is published every weekday (except Mondays) and is read by almost every member of the campus community. This helps to keep abreast with relevant issues concerning the university.

b) Advertise the (recycle@uriacc.uri.edu) e-mail address on the recycling containers and around the campus so that the students/staff and faculty can post suggestions and can respond to recycling efforts. This site can also be used for clarifying any ambiguity regarding recycling materials.

c) The present telephone voice mail system available to all the students in the residence halls is another very direct way of communication. With one push of a button a message can be sent out to all resident students reminding them to empty their recyclables every Wednesday night. 
d) The campus radio station (WRIU 90.3 FM) can also be used as a good means of communication and a reminder for recycling procedures.

e) E-mail newsletter - Instead of sending memos, there can be a bulletin board on the academic computer center network which can be used for sending important messages across campus. This can also be used as a suggestion board.

The residence halls provide a unique case. The demographics are essentially homogenous and this group can easily be targeted because the total population and the configuration of the buildings are known. However, the key to a successful recycling program is the participation of students and the convenience of doing the same. The collective and individual advantages of recycling needs to be publicized. Competitions among residence halls have proven to be a healthy way of involving students (C.J May. Food and Money. Recyc-L [Online] May 15, 1995. 11:23:52 EST ).

The Resident Assistants (RA) are undergraduate students who live in the halls and are part of the student government. They are the most direct contact with all the resident students and thus need to be trained about waste reduction. This will help them to dispel correct information to the students through the floor meetings every week, the RA advisory board meeting with the staff and written comments among students and RA's. This will also help in providing clarifications on a lot of waste reduction issues. 
The committee on Waste Reduction and Recycling has proposed a recycling slogan competition. This would provoke the imagination of the campus community and allow them to think about recycling. A slogan like "URI Recycling Always Makes Sense (RAMS)" or something similar is proposed which would be powerful and the campus community could associate with it. The competition is meant to be campus wide.

Students can also be given information about waste reduction and recycling during the 'orientation' day. A reusable canvas bag can be given to all incoming students as a constant reminder of waste minimization. During the semester there can be an 'informational' week explaining and clarifying recycling issues. The University of Massachusetts, UNH and Brown university all follow this system of communication (Interviews, UMASS, UNH and Brown unversity). Regular workshops need to be conducted in the apartments as well to provide recycling information for the residents. These should consist of information about contents that are allowed as recyclables and collection procedures. Some of these apartments house families with/without children. Exciting things can be done to improve recycling here as well. For example, there can be family picnics and children's competition among apartments. Prizes can be given for maximum collection of recyclables. This way the children not only get involved in collection to win prizes but also become aware of recycling at an early age. These apartments also house a big international student population. Recycling 
information can be sent out in various languages. This would not only be an appreciation of diversity but would also expedite the waste reduction process.

As stated before, Housing and Residential Life and Lands and Grounds together are responsible for recycling on the entire campus. This makes it difficult to channelize information back to students and faculty. There needs to be a single entity overseeing the entire campus operation. Details of the role of this entity is discussed under a separate heading of 'departmental cooperation'. Different universities try different techniques that encourage the students to comply with the recycling procedures. As can be seen from the table below, uncomplicated means of advertisement help the recycling process.

The counterpart target groups to the students are the staff and faculty. The janitorial/custodial staff along with the Printing, Purchasing and the Dining services staff are all key players in this process. They all need to be trained through regular workshops. This is very important because these are the important stockholders in a recycling program.

The faculty can be informed through campus newspaper and the e-mail. They can also help in creating a URI we page for recycling that more personnel can access.

The waste contract vendor also needs to have constant interaction with the waste manager to help streamline the recycling process for URI. 


\section{COLLECTION PROCEDURES}

In the recent years it has been found that the prohibitive transportation costs, poor markets and a lack of industry support has also been major reasons for the low rate of recycling at many universities (Ecodemia, 1995). At URI, the dual management of waste by $H R L$ and $L \& G$ creates confusion. A unified operation will encourage responsibility and stewardship. It would also save time while providing the opportunity to interact with only one central authority.

A Waste Manager in a full time position (when appointed) would look at the trash as well as the recycling aspects. Both these aspects are equally important and interdependent. This individual will track the recycling and figure out the nature of the waste stream as it looks for looks for URI. The WRR committee suggests hiring this individual as well. See Appendix. F for more details.

URI generates approximately 3200 tons of waste a year including food waste. The present waste contract requires the vendor (T\&J Container Systems) to remove trash everyday and recyclables every Thursday.

One of the successful efforts made at various other universities has been to try and reduce the use of office paper. Office white paper is the most widely used commodity on campus because the students, staff and faculty all use it for various purposes. This would help to minimize waste on campus. 
Graduate and Faculty apartments at present do not have any recycling bins in any area. This area provides untapped population which can have a significant impact on the recycling rates for the campus as a whole. Following are some simple recommendations which can prove to be helpful.

1) Provide recycling toters outside these apartments.

2) Collect food waste which can then be used for composting or mixed with the Dining services waste to be hauled as required.

3) As the residents give notice to leave, they can be provided with extra recycling bins during move out. This can be collected by HRL and donated to local charity institutes. Brown university collects materials at the end of the year and distributes them all around Providence. This helps to create a more regional approach and encourages partnership (Recyc-L, [Online] March 29,12:52:08.1996).

4) Recycling Magnets for refrigerators with important information can also be handed out when residents move in.

5) Each apartment needs to have a blue recycling bucket. A damage fee of $\$ 25-\$ 30$ can be charged at the end of the lease for replacement. The University of Vermont charges a $\$ 50$ fine for lost or damaged recycling bins at the end of the year (Recyc-L, Feb 29,1996).

As pointed out earlier, the custodial staff is the backbone of any waste reduction program. At URI as well they play a very big role. The custodial staff is divided into two groups, one that reports to the L\&G and the other to HRL. At present, 
the HRL custodial staff empties the recyclables from the common areas into the toters outside the building whenever required. On Thursdays the waste hauler collects it from all the areas on campus.

A number of measures can be taken to improve the current system of collection. These are the following:

1) Designate recycling areas inside the building where the recyclable can be locked and stored to avoid theft of materials. On Wednesday nights they should be brought outside by the custodial staff for collection on Thursday morning. This also reduces trips made everyday to the recycling bins outside. Toters should be returned to their original places inside the residence halls after the hauler has emptied them.

2) The toters need to be cleaned and maintained. Damaged toters need to be reported to the waste manager.

3) Custodial staff can also be instrumental in tracking regular offenders who contaminate the toters. This type of 'janitorial policing' can alert the offenders. In the future as the participation increases, the custodial responsibility will become more significant.

All the above combined administrative and spatial recommendations will help in improving recycling. These will also assist in a smoother flow of ideas and improvement techniques.

To quote Erica Speigal, Recycling Coordinator, University of Michigan, "As people fill up the recycling bins (e.g. with paper), fewer trash bins will be 
needed." This will reduce the janitorial work and distribute responsibility equally amongst all the members of the campus community. As a result, universities with advanced recycling programs phase out the trash receptacles and replace them with recycling bins in most areas.

Since HRL and $L \& G$ both are responsible for overseeing recycling on campus It makes it difficult to account for contamination. In its reporting, the hauler does not differentiate between the housing areas and the rest of the campus. It is this overlap that creates confusion. A unified operation will encourage responsibility and stewardship.

Also, as participation increases the proceeds from the sale of the recycling materials could be put directly back to the residence halls. This money could be used for programming or physical constructions for the residence halls.

\section{DEPARTMENTAL COOPERATION}

Departmental cooperation is important for any program to flourish on campus. For URI, a single waste manager would prove to be fruitful. This individual will monitor the program from its infancy to maturity. The waste manager when appointed would also be the center of information for any questions regarding recycling. Other waste management techniques like conservation of energy, management of hazardous waste from various laboratories require to be studied. The waste manager would also be responsible for working with the purchasing and the printing departments on campus. 
The printing department would help in creating brochures and other information packages such as laminated posters and table tents. The purchasing department would help in buying reusable materials that would reduce waste.

\section{HAULING CONTRACT}

T \& J Container Systems contract is currently being reviewed by WRR. As the contract comes up for renewal, new specifications could be added according to the requirements of the campus. The contract could require the cooperation of the recycling coordinator from T\&J in order to streamline the contract and make to suitable for URI. Also, the replacement of damaged and poorly painted containers can be requested at the earliest. The WRR committee is requesting color coding of the containers for simplicity so that the campus community can associate with these bins.

\section{CONCLUSION}

There needs to be a multi-pronged attack on the way waste reduction is done on campus in order to mobilize the campus community. As can be seen from examples of other universities, recycling and waste reduction are efforts that the entire campus makes jointly. This leads the way for a behavior change and a change in paradigm over time.

Even though URI makes it very convenient to recycle by placing recycling bins in each room, still the recovery rates are very low. There is no simple answer to 
the problem of waste reduction, but experiences of other universities teach us to first make a commitment. That is the most important first step. Once the support of the higher authorities on campus is gained, then other initiatives can be undertaken. A step towards that has been the creation of the WRR committee. Targeting different groups of customers would be helpful. All groups play important roles individually and collectively. Also, cooperation among different departments will help in expediting the process. This will make the campus environmentally friendly.

All the above recommendations are only but first yet important steps towards improving participation and awareness among the campus community. The university campus is not only an arena for educational attainment but also a place to be sensitive to the environment. The diverse resident community does pose a challenge to implementing a successful recycling program but in a university setting this should be part of a required behavior. An important part of any program implementation is constant feedback and evaluation. The residents need to feel that they are important and make a difference. Awards and competitions are a healthy way to promote this spirit. Waste reduction and recycling efforts can also be forwarded by the judicial system. A constant check on contamination and weightage is extremely crucial to a successful program. With time if the recommendations of the PACE committee are implemented, there can be hope for a greener campus. This can then be marketed to attract students from across the country. 
The last chapter will focus on specific implementation strategies that can be used to realize some of the above mentioned recommendations. It will aim to provide realistic answers to some of the 'how to' questions. 


\section{IMPLEMENTATION STRATEGIES FOR URI RECYCLING}

\section{Chapter IV}

\section{INTRODUCTION}

In Spring of 1996, The University of Rhode Island made a concerted effort towards planned change. The Presidents Advisory Committee on the Environment (PACE) was created. This committee consists of staff, faculty and students from different areas of concentration. The mission of this committee and its subcommittees is to find better ways of managing the resources on campus and to protect the environment. The subcommittee on Waste Reduction and Recycling is a part of PACE. The final recommendations by PACE is to create a Master Plan for URI.

There are many recommendations made by the WRR which need to be implemented. It is to be noted that certain recommendation made as part of this research may overlap or forward those made by WRR. The purpose simply is to maximize the use of all available resources on campus.

This chapter will try to outline the key players responsible for recycling the recycling program development and implementation. The responsibilities would be disbursed to various departments with timelines to achieve the same.

The main departments responsible for program implementation are the following:

1) Housing and Residential Life

2) Facilities and Operation (Lands \& Grounds) 
3) T\&J Container Systems, vendor

4) Printing services

5) Purchasing Office

6) Custodial staff

7) Dining services

8) PACE Committee

9) Faculty

10) Telecommunications Office

11) International Students Services (I.S.S)

12) Academic Computer Center

13) Budget Office

All these departments need to work together to implement the recommendations in the previous chapter. The time lines will be divided into three parts;

a) Summer 1997

b) Fall 1997- Fall 1998

c) Next five years

The tasks are divided into these three categories to avoid overburden on any one department at any particular time. Also, certain tasks essentially fall within the scope of certain defined departments and this needs to be recognized. The other factor is the time required for any approval process through the school system. All these tasks need to be achieved by the year 2002 . By then the participation rates should reach higher than the state mandate of $20 \%$. 
The first set of recommendations include the summer of 1997, and those that can start with the start of the academic year. By fall of 1997, the demographics of the campus would be known and thus the population can be targeted accordingly.

\section{SUMMER OF 1997}

Table No. 2 shows tasks aimed for the summer semester and are to be implemented by the appropriate department.

Table No.2

$\begin{array}{ll}\text { TASK } & \text { DEPARTMENT } \\ \text { Color coding of the recycling containers } & \text { T\& J CONTAINER SYSTEM } \\ \text { Create information packets } & \text { HRL, PRINTING. I.S.S } \\ \text { Place recycling toters in the apartments. } & \text { HRL, T\&J } \\ \text { Table Tents in Dining Halls } & \text { DINING SERVICES, } \\ & \text { PRINTING } \\ \text { Advertise for Waste Manager position } & \text { HRL, L\&G AND PACE }\end{array}$

All these tasks can be accomplished if WRR committee urges these departments to work on these tasks. At present the lack of a Waste Manager leads to lack of coordination among these departments. The hiring of a full time waste manager is essential because this individual could then coordinate the entire operation. Also, the waste manager needs to implement evaluation techniques to gauge the success of any program.

The next set of recommendations are aimed for the next year starting in fall of 1997. These are supposed to encourage participation and have long range results. These need additional planning and approval from various school authorities. 


\section{FALL 1997 TO FALL 1998}

Table No. 3

\begin{tabular}{ll}
\hline TASK & DEPARTMENT \\
\hline Waste audit & HRL, LANDS AND GROUNDS \\
Voice mail to send information & HRL, TELECOMMUNICATIONS \\
Campus Radio for sending information & WRIU 90.3, HRL, LANDS \& \\
& GROUNDS \\
Training for RA's, staff \& Faculty & HRL, T\&J SYSTEMS \\
Hall and apartment competitions & HOUSING AND RESIDENTIAL LIFE \\
New waste contract & LANDS \& GROUNDS, HRL, T\&J \\
& SYSTEMS \\
Waste manger appointed & PACE COMMITTEE, HRL \& \\
& L \& G \\
Recycling bins in/ outside apartments & HRL, T\&J \\
Designated storage areas for reyclables & HRL \& CUSTODIAL STAFF
\end{tabular}

The above table shows the responsibilities of each of the departments. When more than one department is shown, it requires cooperation between them. The next set of recommendations shown in Table No. 4 fall within long range planning.

\section{NEXT FIVE YEAR IMPLEMENTATION STRATEGIES}

Table No. 4

\begin{tabular}{ll}
\hline TASK & DEPARTMENT \\
\hline Food composting & DINING SERVICES, LANDS \& \\
& GROUNDS \\
Janitorial policing & CUSTODIAL STAFF AND THEIR \\
Requirement of reusable packaging & UNIONS \\
Purchasing of recycled products & CUSTODING, HRL, L\&G, \\
& PURCHASING, BUDGET
\end{tabular}

The feasibility of these above mentioned recommendations could be studied by an independent outside agency or as part of student research before being implemented. Some of these recommendations require major capital 
expenditures and thus need careful evaluations. To quote Julian Keniry of National Wildlife Foundation, author of Ecodemia "Even budget-strapped state institutions of higher education, with their often complex decision-making structures, are finding ways to finance comprehensive energy conservation programs with long-range goals in mind. Given enough sufficient support, campus energy officers can involve students and other staff in myriad projects designated to prevent pollution and save money. These projects, whether research programs, building conservation contact networks, or a Green Cup competition have helped to channel student and staff enthusiasm for a clean energy future in ways that are cost-effective for the campuses and compatible with their educational missions".

To quote Jack Debell of University of Colorado, " Financial savings, while not the motivating force behind the start-up of college recycling programs, has been the determinant in the shift of responsibility for recycling from students and other volunteers to full-time facilities and custodial staff." (Ecodemia, 1995).

For URI, the initiative has already started with the PACE committee. Now the implementation wheel needs to start rolling. The subcommittee on Waste Reduction and Recycling can be the starting point. WRR can propose new ideas to the President as the program evolves. 


\section{CONCLUSION}

To quote Tom Kelly of Tufts University, "Writing on a piece of paper is not a sign of lasting success. Without the commitment of those in authority, the policy may not be worth the paper it is printed on" (Ibid. 1995). Although, there is a start with the PACE initiative, an authority needs to ensure that the recommendations are carried out. The student senate can prove to be powerful in that respect. Faculty also can encourage students to research waste reduction procedures and earn valuable credit and experience.

Recycling needs to be more than a preference. A campus is a good place to start changing this preference to priority. As time passes, more students would graduate carrying with them not only a degree, but also a sense of responsibility for the environment. Campus recycling can no longer be ignored at URI, it is a serious issue of local and state magnitude. A campus as big as URI cannot afford to be negligent about its waste reduction procedures. A change needs to occur starting in the classrooms. URI needs to be credible in the local and national arena as an institute of higher learning with a great sense of pride in its environmental awareness.

It has been the effort of this research to provide simple recommendations that can act as a starting point for a more advanced recycling program. This research is by no means exhaustive in its recommendations. With 
improvements in science, technology and attitude various opportunities will present themselves. As a campus community we should be ready to embrace these innovations. At present the most important issue is to make the campus community aware of the grave waste management situation that URI. It generates huge amounts of trash that are choking the landfills and polluting the environment. URI needs to take a stand and take responsibility of its actions as far a waste generation is concerned. There is optimism for the future if the campus community works together in this endeavor. 


\section{REFERENCES}

Bascon David, Hill Gary. (1995). Facilities and Operation Annual Report. University of Rhode Island. Kingston. RI.

Debell Jack. (1994, Sept). Coming of Age: Recycling on Campus. Resource Recycling. Vol. $13 \mathrm{n} 9$.

Fulton Rockwell. (1993, July). Universities test organic recycling. Biocycle. Vol. 34, $n 7$.

Keniry, Julian. (1995). Ecodemia: Campus Environmental Stewardship at the Turn of the 21st Century. National Wildlife Federation. Washington D.C.

Saphire, David. (1995). Making Less Garbage on Campus. INFORM, Inc. New York, NY.

State of Rhode Island, DEM, Office of Environmental Management. (1994-95). Commercial and Solid Waste Reduction and Recycling Annual Report for URI. Rhode Island.

The Heinz Family Foundation. (1995, Jan). Blueprint for a Green Campus: the Campus Earth Summit Initiatives for Higher Education. Washington D.C.

Thomas A. Christopher. (1995-96). University of South Carolina: Environmental Audit. Columbia, SC.

Young John E. (1995, July-Aug). The sudden new strength of recycling. World Watch. Vol. n4.

\section{Electronic Resources}

Recyc- $L$ is an electronic discussion group dedicated to college and university recycling coordinators. To access, e-mail to Recyc-L@Brownvm.brown.edu. The Curc Web Recyc-L Archiver can be accessed by date and topic. archiver@ecoysys.drdr.virginia.edu

CURC Web is a database of information about recycling programs of college and universities which are members of College and University Recycling Caucus (CURC). http://ecosys.drdr.virginia.edu/curc.html 
Campus Contacts via e-mail

Brown University. Kurt Teichert.

Kurt_Teichert@Brown.edu

Eastern Michigan University. Neal Belitsky.

Neal.Belitsky@emich.edu

Harvard University. Rob Gonan.

Rob_gonan@harvard.edu

University of California, Davis. Lin King.

Ltking@ucdavis.edu

University of California, Santa Cruz. Dave Wade.

Dmwade@cats.ucsc.edu

University of Massachusetts. Roger Guzowski.

Rgu@aims.hampshire.edu

University of Michigan at Chicago. James Cahillane.

James_cahillane@fpm.uchicago.edu

University of Michigan at Ann Arbor. Erica Speigal.

Ericas@umich.edu

University of New Hampshire. Becky Herman.

Rjh1@christa.unh.edu or http://unhinfo/unh.edu/

University of Norhtern Texas. Lisa Eiden.

Eiden@hsl.unt.edu

University of Rhode Island. Nancy Hawksley.

Hawksley@uriacc.uri.edu

University of Vermont. Dennis Clark.

Dclark@moose.uvm.edu

Yale University. C.J May.

May@quickmail.yale.edu 


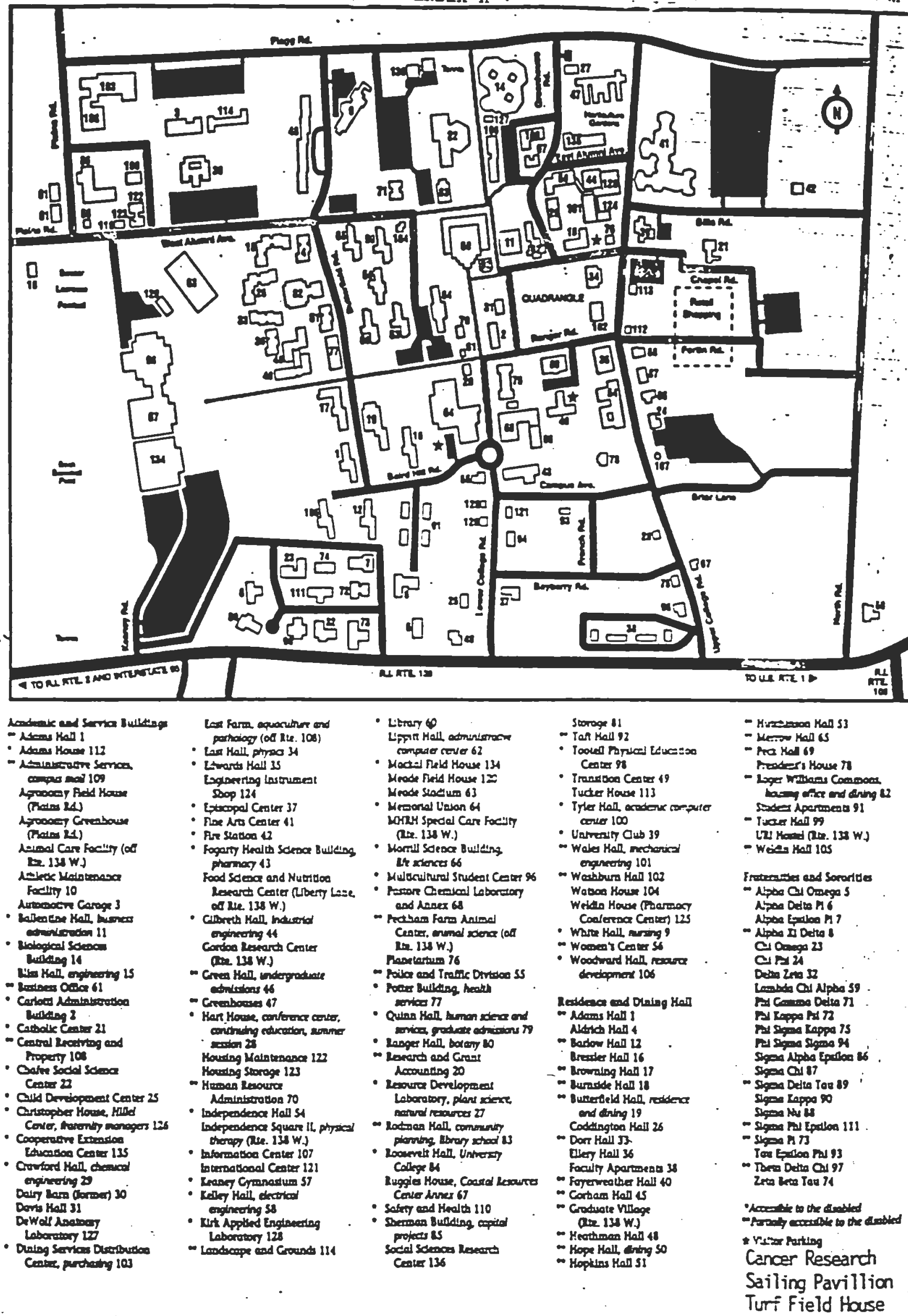


NOTE, DJNING HALLS LOCATED AT

RDCERVILLIAMS,BUTTERFIELD AND HDPE.

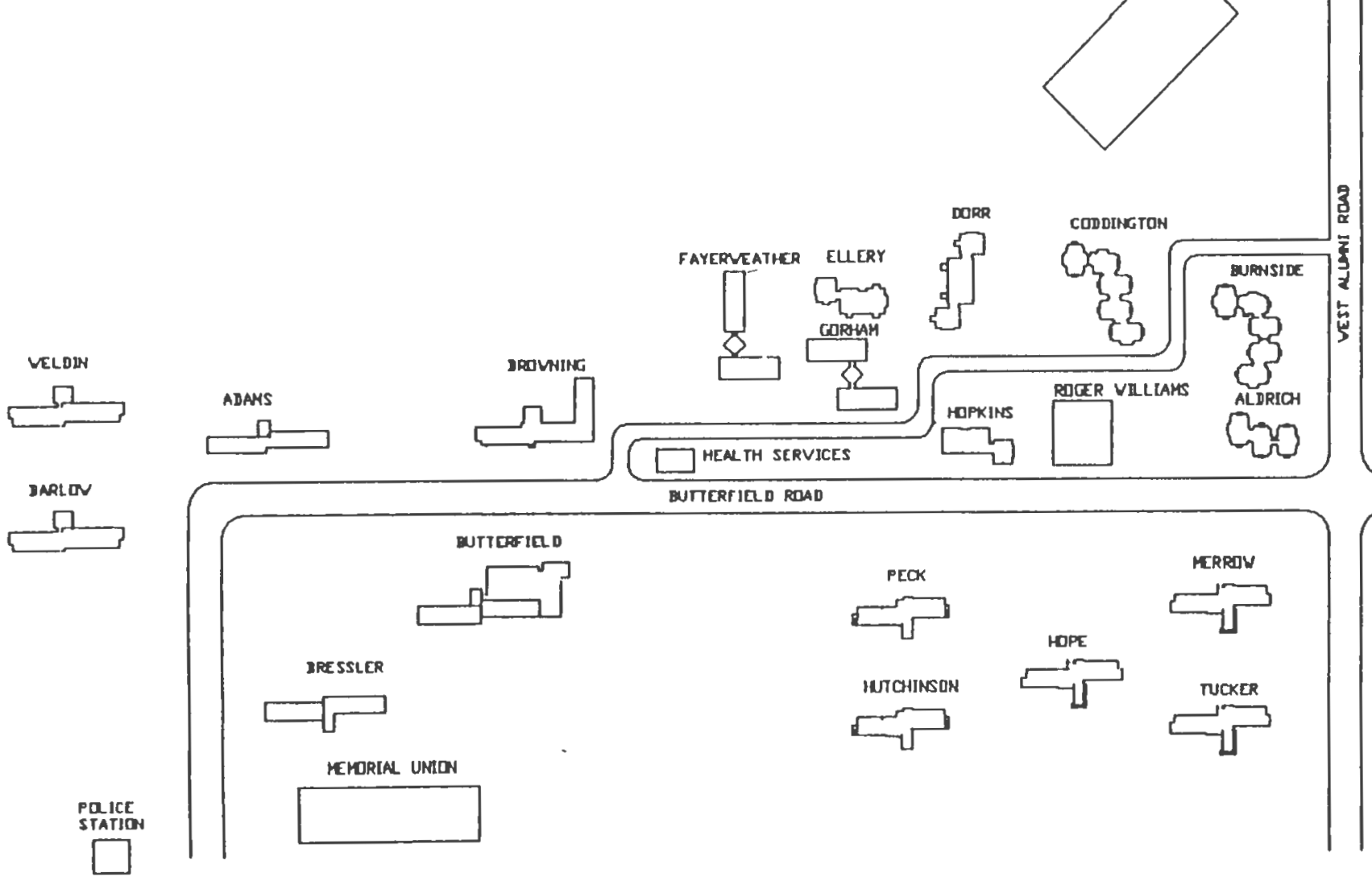

MAP OF RESIDENCE HALLS

UNIVERSITY OF RHODE ISLAND KINGSTON 


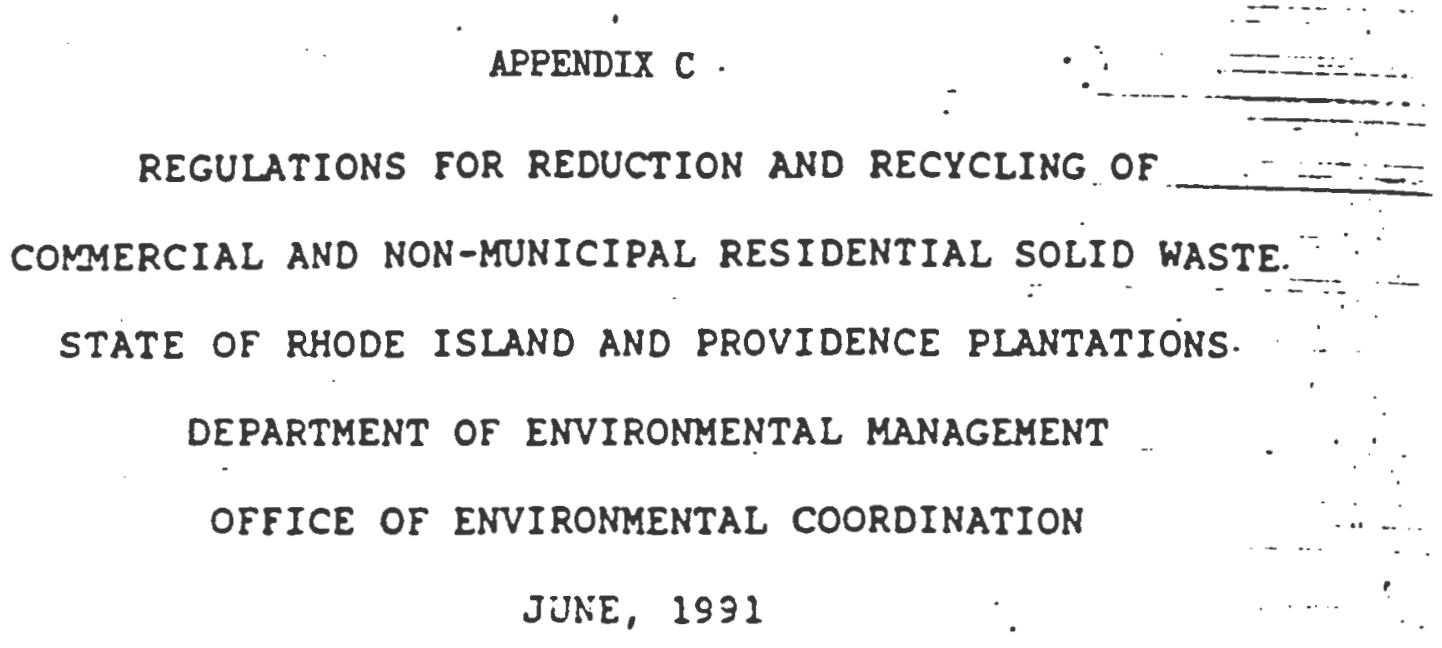

1. Authority

2. Purposes

3. Definitions

1. Applicability

5. Recyclable Materials

6. Segregation of Recyclables from Commercial solid maste

7. Solid waste Reduction and Recycling Plans

8. Implementation schedule

9. Reporting

10. Enforcement

11. Construction.

12. Severability 


\section{AUTHORITY}

These regulations are adopted pursuant to chapters $-23-18,8-2,-23-$ $18.9-1,23-18.9-7,23-19-3,23-19-5,37-15,42-17,1-2,42-17.6$ and $42-35(3)$ et seq.

\section{PURPOSES}

These regulations establish the requirements for the reduction and recycling of commercial and non-municipal residential solid waste. The program is to be administered by the Department of Environmental Management in cooperation with the solid Waste Management Corporation.

The purposes of these regulations are:

a.to define the recyclable components of commerciz! and nonmunicipal residential solid waste,

b.to set schedules for recycling commercial and non-municipal residential solid waste, for subritting source reduction and recycling plans and for reporting source reduction and recycling activities, and

c.to establish enforcement procedures for these regulations.

\section{DEEINITIONS}

For the purposes of these regulations, except as provided below, the general definiticns and abbreviations set forth in chapters 23$18.9-7$ and 23-19-5 of the General Laws of Rhode Island shall apply to these regulations.

"Broker" means any person who engages in the business of accepting recyclable material consisting, in whole or in part, of segregated recyclables from comnercial solid waste generators in Rhode Island.

"Commercial solid waste" means all solid waste except: hazardous waste, as defined in Chapter 19.1 of the Rhode Island General Laws; municipal solid waste and non-municipal residential waste, as defined in these regulations.

"Corporation" means the Rhode Island Solid Waste Management corporation.

"Corruaated paper" means corrugated containers, substantially clean and dry, empty and free of wood, plastic, polystyrene and other packing materials. Wax coated and /or wire reinforced corrugated is excluded from this definition.

"Department" means the Rhode Island Department of Environmental Management. 
"Manager of multi-unit housing" means any person having the responsibility for solid waste management in a multi-unit residential housing complex or facility, the residents of. which generate non-municipal residential solid waste.

"Municipal solid waste" means that solid waste generated by the residents of a municipality in the course of their daily living. the disposal of which the governing body of the municipality has undertaken in the discharge of its duties to protect the health of the municipality. Municipal solid waste does not include solid waste generated wy residents of a municipality in the course of their employment or that generated by any manufacturing or commercial enterprise.

"Non-municipal residential solid waste" means solid waste generated by the residents of a municipality in the course of their daily living for which the governing body of that municipality does not accept responsibility for disposal. Non-municipal residential solid waste does not include solid waste generated by residents of a municipality in the course of their employment or that generated by any manufacturing or commercial enterprise.

"Person" means any individual, firm, institution, partnership, association or corporation, public, or private, organized or existing under the laws of the state or other states including federal corporations, but excluding municipalities.

"Seareqation of recyclable materials" means separating or keeping separate recyclable materials fror solid waste before it is delivered to a solid waste disposal facility.

"Sorted colored ledger paper" consists of printed or unprinted sheets, shavings and cuttings of colored or white sulphite or sulphate ledger, bond, writing and other papers which have a similar fiber and filler content, and which are free of treated, coated, padded and heavily printed paper, carbon paper and nonpaper materials.

"Telephone directory" shall mean a soft-cover listing of telephone numbers and addresses by telephone listing territories commonly listed alphabetically or by occupation and distributed to households and businesses in behalf of telecommunications utilities or private advertisers.

"Wood waste" shall mean lumber, pallets, crates, plywood, particle board, and saw dust, substantially free of contaminants. contaminants include: lead paint, banding, bolts over 1 and $1 / 4$ inch diameter, shingles, pipe, formica, plastics, and preservatives. Construction or demolition debris that cannot be readily separated is excluded from this definition. 


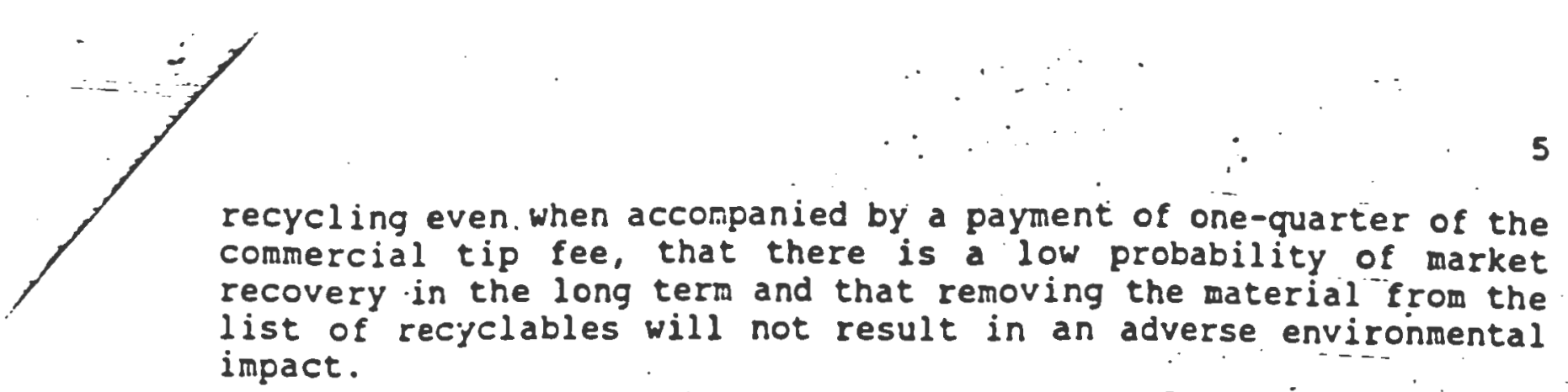

6.

SEGREGATION OF RECYCLABLES FROM COMGRRIAL BOLID WASTE

Segregation of recyclable materials means separating the recyclable materials and keeping them separate from solid waste to prevent contamination and maintain marketability before the recyclables are delivered to solid waste disposal facility. All generators of commerciat-solid waste-shati-segrëgatc recyclables from the waste that they generate and shall keep a record of the amount and types of the recyclable materials segregated. In 1989, segregated commercial and non-municipal residential solid waste shall cont: in no more than 30 s recyclable material by weight. After $15 \%$. segregated commercial and non-municipal residential solid waste shall contain no more than 208 of recyclable material by weight.

-

7. SOLID WASTE REDUCTION AND RECYCLING PLANS

All generators of commercial solid waste and managers of multi-unit housing in which non-residential municipal solid waste is generated must prepare a plan for source reduction and recycling. These plans shall include a waste audit, a description of the process by wich recyclable naterials are to be segregated from the waste and a plan for reduction of the amount of solid waste generated. Flans should include an analysis of the possibility of recycling -..aterials not currently defined by these regulations as recyclable. No later than 90 days before these plans are due, the Department will make guidelines available to provide detailed instructions for the preparation of these plans.

8 .

IMPLEMENTATION SCHEDOLE

After 31 December 1988, recyclables must be segregated from commercial solid waste delivered to a corporation disposal facility. Recyclables must be segregated from non-municipal residential waste no later than 180 days after the municipal recycling program begins in the city or town in which this waste is generated or one year after these regulations become 'final, whichever date is later. The manager of multi-unit housing in which non-residential municipal solid waste is generated may petition the Department for an extension of the compliance dates established in this section. Such a petition should demonstrate an inability to comply with these regulations in a timely fashion because of conflicts with local zoning or unusual difficulties in providing for separation and storage facilities. It is the responsibility of the generator of commercial solid waste or the manager of multi-unit housing in which non-residential municipal solid waste is generated to segregate recyclables at the source. 
These regulations apply to: any person who generates comercial solid waste, regardless of whether such commercial solid waste is disposed of in Rhode Island: any manager of multi-unit housing in which non- municipal residential solid waste is generated; -any person who segregates recyclables from commercial or nonmunicipal residential solid waste or who delivers commercial or non-municipal residential solid waste to a corporation disposal facility; any broker and any operator of a solid waste disposal facility located in Rhode Island.

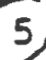

RECYCLABLE MATERIALS

For the purpose of defining those components which must be segregated from commercial solid waste, the following materials are defined as recyclable: corrugated paper: sorted colored ledger paper or any component thereof: wood waste; used lubricating oil; vehicle batteries: automobiles: HDPE plastic milk and water containers: PET plastic soft drink containers: all materials defined as recyclable under the Municipal Recycling Regulations as the same may be amended from time to time including, but not limited to: glass food and beverage containers, steel or tin coated steel cans, aluminum, newsprint, and white goods; and, after January 1, 1992, telephone directories: after January 1, 1993, leaves and yard wastes. For the purpose of defining those components which must be segregated fron non-municipal residential solid waste, the following materials are defined as recyclable: class food and beverage containers, plastic milk coniainers, plastic soft drink containers, newspaper, tin coated steel cans/steel cans and aluminum. Th.ese naterials must be segregated and kept in a condition to meet minimum market standards. The raterials to be included may change from time to time depending upon new technologies, economic conditions, characteristics of the waste strean, environmental effects or other factors.

Sutseguent to the point of generation, no person shall combine unsegregared commercial or non-municipal residential waste with any other waste such that the combined waste would be classified as segregated commercial waste.

Any person has the right to petition the Department to add a material to the list of recyclable materials. Such a petition should offer a binding contract to accept for recycling at a location in the state of Rhode Island when accompanied by payment of one-quarter of the commercial tip fee the total amount of that material generated in Rhode Island as a component of commercial or non-municipal residential solid waste. If in addition the petition demonstrates that recycling of a material will result in a significant improvement in environmental quality in Rhode Island, the Department will consider adding to the 1 ist of recyclables a naterial which will be accepted at additional reasonable cost to the supplier.

Any person has the right to petition the Department to remove a material from the 1 ist of the recyclables to be segregated from 


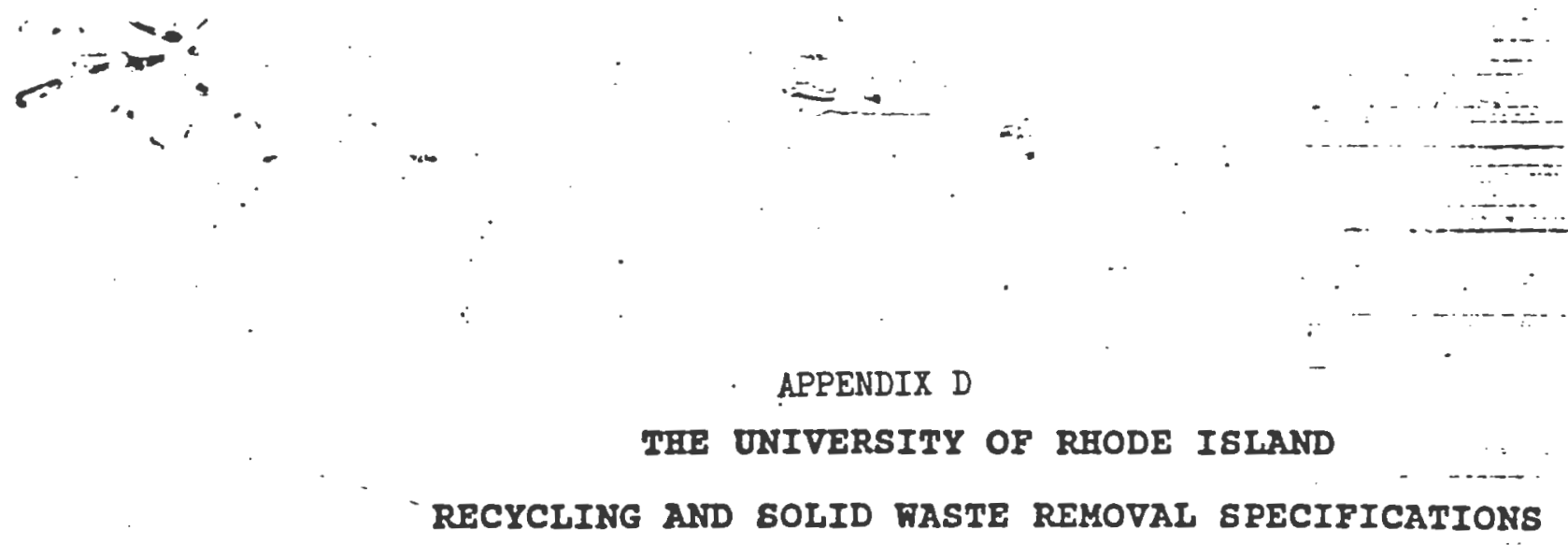

RECYCLING AND GOLID WASTE REMOVAL SPECIFICATIONS

TEE ONIVERSITY OF RHODE ISLAND DEPARTMENT OF FACILITIES \& OPERATIONS RINGSTON, RHODE ISLAND 02881-0801

L. Robert snell, Acting Director David D. Bascom, R.L.A. - Assistant Director, Landscape \& Gounds Division

February - 1995 
specifications

1.0 General Conditions: Vendor shall provide all labor, materials, containers, tools, equipment and total services for removal of solid waste and recyclables from kingston Campus and Narragansett Bay Campus. The vendor shall provide all containers and maintenance thereof as specified, provide for all pick-up and hauling of solid waste and recyclables and provide for payment of all fees and licenses required for disposal.

1.1 Mandatory Pre-Bid Conference: All bidders shall attend a pre-bid conference to be held at the oniversity of Rhode Island for the purpose of clarifying: specifications and procedures, definition of bid instructions, methods of operations, legal requirements: campus limitations: and contractor responsibilities. Failure to attend this conference shall result in disqualification of any bid submitted.

1.2 For the purposes of this request, it will be assumed that all rubbish removed from state premises will ultimately be disposed of at the central Landfili in Johnston, and that all bids are predicated on this basis, unless the bidder makes a clear statement to the contrary in the bid documents.

(NOTE: The state reserves the right to reject such bids as non-responsive.)

1.3 Vendor will not be allowed to subcontract any services at any location described in these specifications.

2.0 Capacity and Frequency of Removal: Vendor shall provide front end loading containers, newly painted, fully operable and labeled for collection at the locations specified herein.

2.1 Kingston Campus:

Container capacity and frequency of collection -

(1) september 1 through May 31; and

(2) alternate summer schedule. 
Payment of Tipping Fees: The solid waste removal vendor shall be required to pay all tipping fees under this contract directly to the receiving agency. The University of Rhode Island shall reserve the right to direct pay tipping fees to the solid waste Management Corporation or to the Town of south Kingstown. The oniversity shail notify the vendor in writing within thirty days prior to any decision to make such direct payments.

6.1 The state will not consider requests for price modification as a result of changes in tipping fees, except where such changes are supported by an announcement by the Rhode Island Solid waste Management Corporation of a change in the disposal fee for the. central Iandfill in Johnston. It is expected that all changes in published tipping fees ghall be an additive or subtractive pass-through to the state, with no aditional costs for other services.

Duration of contract: This is a one year contract and is subject to no more than two annual renewals at the sole discretion of the state Purchasing Agent.

3.0 The University shall have the right to withdraw from this contract after ninety $(90)$ days written notice.

Payment: Vendor shall send invoices monthly to:

Accounts Payable 103 Administration Building U.R.I., Ringston, Rhode Island 02881-0801

Recycling: The University has been classified as a commercial generator of solid waste and therefore must comply with all commercial recycling regulations as defined by the Department of Environmental Management's June 1991 mandates. The Oniversity has determined for the purposes of these specifications that the recyclables removed by the vendor shall become the sole property of the vendor at the time they are collected by his equipment. All source separated materials shall be deposited at a recycling market or at the Materials Recovery Facility (MRF) at the central Iandfill.' In no case will the contractor be allowed to transport source segregated materials to a "burn to energy" facility.

10.1 Vendor shall provide recycling collection containers for all buildings and specified locations. cardboard collection containers shall be placed at locations specified by this department. containers shall be marked and labeled and painted in a contrasting color from trash containers. They are to collected weekly. 
ipecifications

10.2 Three (3) sizes of "toters" shall be provided, a 105 gallon, 65 gallon size, and a 30 to 35 gallon size. Toters must be clearly labeled office paper/Computer Paper: Newspaper; and Aluminum, Plastic, Glass and Tin Containers; constructed of heavy duty polyethylene. plastic: hinged lids; and 12 " wheels. All toters shall be of the same style, color, and mesufacturer. Toters shall be wheeled from buildings by University personnel for curbside collection.

10.3 A container shall be provided for the collection of telephone books at a time specified by this Agency for a nirimum of a one week period, three times per year (NYNEX, Narragansett, U.R.I.).

10.4 The vendor may suggest streamlining techniques and/or alternatives to the existing recyciing program for the University's review. Changes in methods of collection, frequency of collection or other modifications without prior approval of this Agency shall not be permitted.

10.5 Documentation for all recycled materials shall be forwarded to this Department on a weekly basis, indicating materials, quantities, scale weights, vehicle I.D., dates, and market.

10.6 The vendor shall provide a recycling coordinator for the duration of the contract to assist the oniversity in managing the recycling program, developing community awareness, monitoring collection and disposal, and providing technical information as part of the recycling service. The coordinator may be required to address or participate on committees, organizations or similar groups.

10.7 The University has reported annual reductions in solid waste for the following products and quantities for the Fiscal Year ending June 30, 1994:

\begin{tabular}{|l|r|}
\hline Newspapers & 31 Tons \\
\hline Mixed Office Paper/Computer Paper & 12 Tons \\
\hline OcC & 124 Tons \\
\hline Cans, Glass, Plastics & 54 Tons \\
\hline Phone books & 5 Tons \\
\hline Scrap Metal & 43 Tons \\
\hline Leaves/Yard Faste & 25 Tons \\
\hline
\end{tabular}




\section{URI RECYCLES}

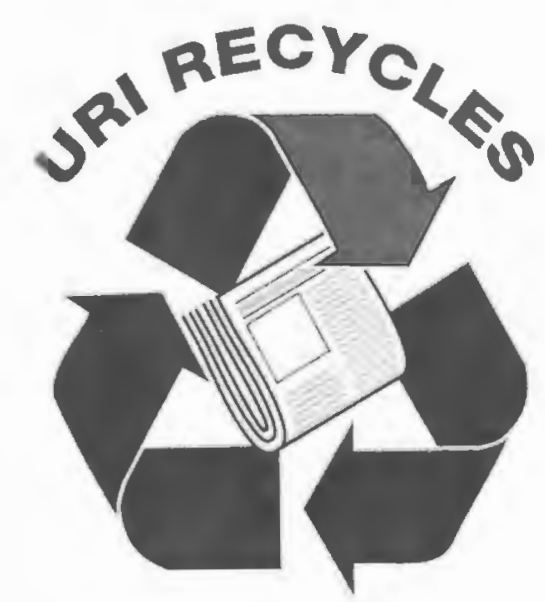

\section{NEWSPAPER \\ Newsprint Only}

CO-MINGLED

Aluminum Cans

Plastic Beverage Containers Glass Bottles Tin Containers
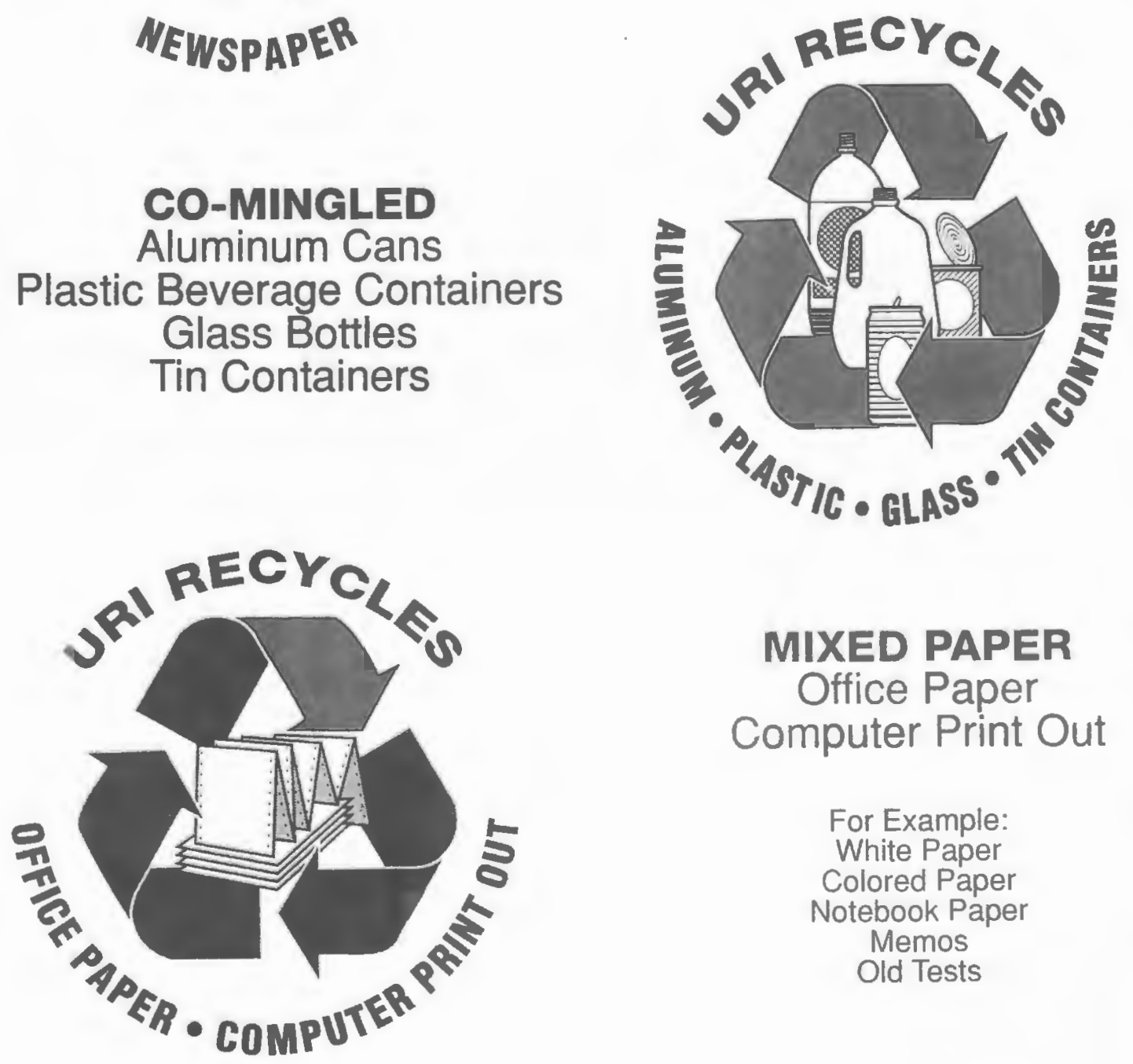

For Example:

White Paper

Colored Paper

Notebook Paper

Memos

Old Tests 


\section{APPENDIX $F$ \\ PRESIENT'S ADVISORY COUNCIL ON THE ENVIRONMIENT \\ SUBCOMMTTTEE ON WASTE REDUCTION AND RECYCLNG}

The subcommittee researched waste reduction and recycling at the University of Rhode Island and at other colleges and universities. We studied URI's current contract and observed trash and recycling collection areas on the Kingston campus. We also visited the University of Massachusetts at Amherst, the University of Vermont, Brown University and Northeastern University. One subcommittee member joined the College and University Recycling Council of the National Recycling Coalition, the Northeast Collegiate Recyclers Coalition, and the Campus Ecolog: Project of the National Wildlife Federation.

This subcommittee proposes the University of Rhode Island formally endorse the Heinz Foundation Blueprint for a Green Campus: The Campus Earth Summit Initiatives for Higher Education. We encourage URI to focus particular attention to Chapter VI Reduce Campus Waste.

We are greatly concerned with the universiry's recycling rate of only $10 \%$. This rate has basically remained the same since the inception of recycling to URI in 1989. Other colleges and universities nationwide report recycling rates of between $10 \%$ to $60 \%$.

Our program needs to focus on the areas of education, collection, contamination and materials. Following are some suggestions for further consideration:

- Develop an educational campaign to improve the awareness of students, faculty and staff regarding source separation and contamination.

- Create a logo and slogan for URI recycling. 
- Provide new employee orientation to recycling. Consider annual or bi-annual employee refresher training.

- Work within areas and departments of the university to identify and solve recycling problems specific to their operations.

- Have personnel available to give presentations to departments, classes, residence halls, coffee hours, etc. on recycling policy and procedures.

- Develop an environmentally responsible purchasing policy that encompasses the procurement, whenever possible or practical, of products made from recycled goods.

- Make the University of Rhode Island a model for closed loop recycling.

- Create a program for the composting of pre- and post-consumer food waste.

- Publicize the newly opened e-mail account entitled "recycle $\underline{a}$ uriacc.uri.edu." This mailbox was established at the end of fall semester 1996 for housing recycling assistants to respond to questions, concerns, suggestions and iceas about recycling at LRI.

This subcommittee encourages the university to reassign an employee to ser.e as a full time university waste reduction'recycling coordinator, as suggested in Chapter VI Reduce Campus Waste, to manage an effective and responsive program encompassing all four LRI campuses.

Respectfully submitted on January 16, 1997 by Nancy Hawksley for the PACE Subcommittee on Waste Reduction and Recycling: Jim Cole, Joanne DiBello, Michelle Eaker, Tom Husband and Winston Knight. Additional input by Zachary Peloquin and Beth Ridout, student recycling assistants. 
- Consider in-house collection of recyclables from the Kingston and Narragansett Bay campuses.

- Provide a box truck in good condition, painted in school colors and featuring the newly designed logo prominently featured, to be visible to university community members on a daily basis.

- Insist that the contractor's recycling truck has appropriate and clearly visible signage, whether collecting from one collection area on the Kingston campus or from each area on all campuses.

- Allow for growth and expansion of recycling when mandated, in terms of compliance by all members of the university community and in terms of materials subject to recycling.

- Provide all necessary receptacles at all appropriate indoor and outdoor locations. Recycling containers should be adequately and comprehensively labelled. They must be of a color such that all members of the university community can recognize them as being for the sole furpose of the collection of recyclable materials.

- Discourage staff members from removing aluminum or any other high priced commodity from university: propert:

- Landscape trash enclosures in the residential life area. Build new ones where none presently exist.

- Study the feasibility of trash compactors inside the residence halls. Study the feasibility of indoor trash rooms. Consider toters for trash collection from the residence halls.

- If the university ultimately decides to continue using dumpsters to collect trash from the residence halls, have them painted in earth friendly colors. Require them to be new, without side doors, and no larger than six cubic yards. 